\title{
Changing Family structures/values and the Incidence of Human Trafficking in Edo State
}

\author{
Bernard E. Owumi \& Patricia Awa Jerome \\ University of Ibadan, Ibadan \\ DOI: $10.36108 / \mathrm{NJSA} / 7002 / 50(0180)$
}

Vol. 5 Issue 1, 2007

\begin{abstract}
This paper attempts to unravel the underpinning factors that-account for the upsurge of human trafficking in Edo State, Nigeria. The discourse is hinged on the Mertonian concept of innovation which explains the circumvention of societal mainstream values and employed as a circuit and routes to achieving societies collectively subscribed goals. The aims and objectives of the study include: identifying the changes in family structures that predispose parents to trafficking their children; examining the changes in family values that predispose parents to trafficking; discussing the perception of parents about trafficking their children and finally explaining the reasons for the persistence of human trafficking despite attempts to curb it. Focus group discussion (FGD) and in-depth interview methods were used in collecting data. The study revealed that parents are predisposed to trafficking their children due to poverty, unemployment, greed, ignorance, illiteracy, polygyny, distortion of social values, 'dysfunctional families among others.
\end{abstract}

\section{Introduction}

The family is a small but basic unit in the society, which serves as a pillar to ensure that society stands firmly. It provides a socially approved context for childbearing, child-care and for the education of its younger members (Otite $\&$ Ogionwo, 1979). From this viewpoint, the welfare and education of children and younger members of the family are responsibilities of family members both nuclear and extended. However, these values are giving way to some other modern values. Extended family members visit their relatives in the cities with the intention of seeking for greener pastures. During this period, members of such nuclear families are not only expected to cater for themselves but also for those members of their extended family.

In order to meet up with these expectations the persons saddled with these problems in the families are pushed to look for other viable means of survival, following the fact that the resources for acquiring the unlimited wants of man are very scarce. As a result, there are emergent unacceptable values from the socially" approved" to the "available" which in most cases are some social vices permeating the society of which child trafficking is a part. This in some societies especially Edo state is viewed by some parents as lucrative and attractive (Onyeonoru, 2001). There are some instances where some parents withdraw their children especially daughters from both primary and secondary schools to traffick them abroad for quick money. The victims get there to accumulate wealth and retire some proceeds back home to their parents after their recruiters must have freed them. This usually takes 
a long period while the victims are exploited (Mirkinson, 1994, Basil 2000; Nwoha, 2006).

According to Idia Renaissance (a centre designed by Eki Igbinedion to control the phenomenon of girl trafficking in Edo state), "while every black woman in Italy is seen as a potential prostitute, the average Italian who knows nothing about Africa or Nigerians only talks about the "Edo's and Binis" which have come to be associated with the Africa axis of human trafficking, being the home of $90 \%$ of trafficked victims encountered in Italy. This has largely tarnished the reputation of the Edo in particular and Nigeria as a whole.

Human trafficking and its attendant consequence overtime has become a social problem that has attracted the concern of the Nigerian community. Human trafficking does not only tear children away from the protection of their parents, but is also perilous to their well being. As a result of trafficking, the deadly disease HIV/AIDS has been spread both at the individual and collective levels so that while fighting to curb prostitution and reduce HIV/AIDS, the phenomenon of human trafficking has become another headache. It is worse and saddening when we consider the number of victims who have suffered from trafficking. One out of every five Nigerians trafficked to Burkina Faso was reported dead as a result of illness or accidents while others contracted sexually transmitted diseases including HIV/AIDS (Harsch 2001) The pain of losing these victims to such social vices amongst family members are other issues that threaten order and stability in the society.

It is against this background that this paper attempts to examine the family structure/values with a view to ascertaining the trend to change and its attendant consequences. The paper also examines the reasons for the persistence of human trafficking in spite the efforts to stem it. Finally, parent's perceptions of the phenomenon are examined. The study was conducted in Benin City in Edo State. This location was selected because most of the individuals who have been repatriated after being trafficked were reported to come from Edo State (Gideon 2003, UNICEF 2001). Moreover, the city is also said to be filled with vibrant youth whose common interest is the desire to make quick money or travel abroad (Nwoha, 2006). The study population consists mainly of young girls who have been trafficked and are undergoing rehabilitation at a skills acquisition centre at Aduwawa and Idia Renaissance in Ihama as well as parents of these girls and others who are involved in human trafficking. Data collection for this study was done using in-depth interviews and focus group discussion methods. The interview section was conducted in the rehabilitation centres for victims of trafficking and those who are vulnerable to trafficking were traced through the key informant and snowballing methods.The Focus Group Discussion sections were conducted with parents and young girls in Oko villages and Ihama. The children included those in all forms of labour especially street hawkers, pure 
water sellers and housemaids. While parents included mostly traders who belong to the lower class. These were purposively selected because they are said to be easily deceived and convinced into trafficking (Nwoha, 2006).

Twenty-two girls from the selected rehabilitation centres and eighteen parents were interviewed. Altogether totalled 40 respondents. Furthermore, five focus group discussions were conducted among parents and children respectively at Ihama and Oko in Benin City. Each group consisted of 5 to 7 respondents. The study was strictly qualitative research due to the sensitive nature of the subject. The Descriptive method was employed in the analysis of findings. Thus, data were transcribed, sorted and analysed.

\section{Literature Review}

\section{Family Structure}

There are various forms of family structure. The nuclear or elementary family consists of husband (father), wife (mother) and children. The children may be biological or adopted members of the family. The family performs a universal function for the maintenance and continuity of organized social existence (Chinoy, 1967).The family is a social structure, which according to (Murdock, 1945) is produced through cultural evolution in every human society and is presumably the only feasible adjustment to a series of basic needs. These needs are identified as sexual, economical, reproductive and educational.

According to Davis (1954), the major social functions of the family are reproduction, maintenance, social placement and socialization. Chinoy (1967) further stated that the family may play an important role in relation to the economic life of the society, constitute a significant mechanism in the structure of political authority and occupy an important place in religious activities. One can therefore view the family as the nuclei unit in the society within which all other social institutions operate. The family typically provides an accepted and approved channel for satisfying personal needs for sexual gratification, emotional response and social support. Davis (1945) argued further that reproduction, maintenance; placement and socialization are the core functions with which the family is always and everywhere concerned. Although, there may be a great variation from one society to another in the precise manner and degree of fulfilment of these functions, but they seem to be the major ones which universally requires a family.

\section{Changes in Family Structure}

Giddens (1991) took his time to explain that before industrialization, most families were units of production, working the land or engaged in various crafts. Even people who establish their own families for procreation tended to live and work in family settings. In -modern families, children grow up in the household and, continue to live there while at school. Before this time, the care and maintenance of children in the society was not the sole responsibility of the family alone, rather the community participated. This was the family 
that Stone (1977) referred to as the open lineage family, which was the nuclear family living in a small household, but deeply embedded in community relationships, including those with other kin. The family was not clearly separated from the community, and was at this time not a major focus on emotional attachment or dependence on its members. Socialization and welfare of children at this point was a communal function.

The next was the restricted patriarchal family lasting from early 16th century to the early 18 th century. Here, the nuclear family became a more separate entity distinct from ties to other kin and to the local community. This phase of family development was associated with a growing stress on the importance of marital and parental love as well as a growth in the authoritarian power of fathers.

According to Stone (1977), the restricted patriarchal family was progressively replaced by the closed domesticated nuclear family, a group tied by close emotional bond having a degree of domestic privacy and pre occupied with the rearing of children. This type of family organization persisted into the twentieth century and was marked by the rise of affective individualism, the formation of marriage ties based on personal selection guided by the norms of romantic love. This type of family became universal in western countries with the spread of industrialization.

According to Bonnie (2001), the nature of production and consumption initially shaped not only the family structure but also family relations. Therefore, families had to produce enough to cover their consumption needs. In this wise, the labour of all households were required to meet consumption hence the labour of each family member in this context was highly valued. Furthermore, families in this context adopted many strategies to ensure household subsistence so that balancing labour and consumption was an important strategy. They could either hire more hands if they needed more labour and to be able to feed others. On the other hand, they could send out their child or children to live with another family as a servant if they had to support too many people. In a study conducted by Owumi et al (1998), amongst 1,454 persons in Lagos, they observed that $56.6 \%$ of the respondents had extra mouths to feed, while $36 \%$ had two or more to feed. By these figures it is obvious that over $92 \%$ of the respondents had an extra mouth to feed in their households.

As a result of instances like this, family members including parents in Edo state give out their children especially girls to live with other family members as house helps so that their education and some other needs of the family would be met through their relatives. Others are trafficked abroad in order to make money, and accumulate wealth for the family (Basil, 2000, Onyeonoru, 2001, Nwoha, 2006).

Giddens (1991) stated that family systems are diverse and begin from all kinds of starting points in the process of change. There are differences in the 
speed at which change is occurring, and there are many reversals and counter trends. For instance, in the Philippines as is also the case in Nigeria, a higher proportion of extended families are found in urban areas. Cousins, nephews, nieces and other extended family members leave the rural regions and go to the cities' to live with their relatives to try to take advantage of the employment opportunities and resources available there. In some cases, grandparents move in with their children's family and help to run the household and bring up the children, while the younger generation is engaged in outside employment (Hollinger and Haller, 1990). The younger generation is therefore left with the great task of ensuring the economic survival of themselves and members of the extended family that live with them. In a situation where employment opportunities become scarce and almost unavailable, they seek for various available means, which could be societal and unapproved as explained by Merton (1949).

(Gold, 2002) emphasized that the greatest changes that have affected the forms and functions of the family coincided with and were the product of the urban and industrial revolution. He stated that what emerged during the early periods of this transformation was a displacement of the extended family as a dominant form of family organization by the smaller and more mobile nuclear family.

In the same vein, Giddens (1991) also explained that part of the direction of changes that occur in family patterns worldwide is that there is a general trend towards the extension of children's rights. According to Carter and McGoldrick (1999), respect for parents and obligations to care for elders in traditional patriarchal society were based on their control of resources, and reinforced by religious and secular sanctions against those who did not go along with the ideas of the dominant group. However, in subsequent years, the increasing ability of younger family members to determine their own fate in marriage, work and economic security, and the power of elders to demand for filial piety is reduced. In Nigeria, this does not undermine the fact that young family members are expected in these modern days to cater for themselves, their elderly parents and other members of their extended families.

In line with the above, Chinoy (1967) emphasized that changes in family and kinship structures occasioned by industrialization can create a serious problem both for those who have to adjust to new circumstances and the society as a whole. The attenuation of kinship ties frees the individual from some traditional constraints and responsibilities but it also detaches him from obligations and attachments that help give life' order and meaning. The lessened importance of the family as a co-operative economic venture is coupled with greater demands upon the marital relationship itself and therefore upon the individual's capacity to adapt himself to the personal needs and qualities of his spouse. These changes expose men and women to uncertainties and personal conflicts and contribute to an increased frequency of family disorganization. 


\section{Family Disorganization and Human Trafficking}

Historically, the family came under intensive pressure as an institution for socialization during the economic crisis and the insensitivity that accompanied the consequent reforms in Africa (Onimode, 1989, Woodward 1992).

The problem of economic survival eroded social norms that emphasized group solidarity and social integration that support the moral order. Due to global economic recession, parents no more take care of their children but leave them in the hands of housemaids. Most times, the parents of these kids are so engrossed in their work that they hardly have time to relate with their kids. Some kids do not even recognise their parents when they see them. This is partly because the parents are hardly available or not living with them because of occupational migration. Parents apart from failing to adequately socialize their children and wards in accordance with societal norms go further in some cases to promote immorality by acting as negative role models to their children. Some Benin parents persuade, compel or actively participate in trafficking their children for the sex trade abroad (Onyenoru, 2001).

\section{Separation/Divorce; Implication for Trafficking}

Divorce may not be a very rampant phenomenon in Edo state because of the legal processes involved but separation of parents is very rampant. Such separation may be temporary which could last for a few months to as long as over a decade, while some other separation could be permanent as both parents may even decide to remarry and continue their lives as is sometimes the case. Children from separated homes experience some emotional problems. Divorce or separation most times creates emotional distance between parents and children (Carter and Mc Goldrick, 1999). It takes extra effort even for the mother or father living with the child to bridge this distance especially if he or she has remarried.

Research indicates that children often suffer marked emotional anxiety after the separation of their parents. Wallerstein and Kelly (1980) discovered in their study that almost all the 130 children they studied experienced intense emotional disturbance at the time of their parents divorce. They observed that one-third of the children were actively dissatisfied with their lives, depressed and felt lonely even in some cases where the parents with whom they were living had remarried. They further observed that children from such homes experience problems of confusion and fear, frequently worried deeply about the effect of the separation on their future and often expressed feelings of anger. The researchers finally concluded that children fare better when they have a continuing relationship with both of their parents than when they see only one parent regularly. 
The implication of this is that when children from separated homes experience, depression, dissatisfaction, fear and loneliness, they tend to leave their homes or even runaway in search of the other parent. They also tend to look for places where they can have opportunities to seek for satisfaction, friendliness and a sense of belonging. During this period, they meet with the wrong peers or even fall victim to traffickers (Harsch 2001). More so, reports have revealed that children from homeless or separated homes are more vulnerable to trafficking (Nwoha 2006).

\section{Changes in Family values}

Values according to Ugwuegbu $(1984,1987)$ are the goals people work for. They are those elements in a person's behaviour that show how a person has decided to use his or her time, energy and life. Values determine where people put most of their energy what they work for and the way they go about that which they do. They represent something important in human existence. Rokeach (1970) says that value is a disposition of a person. It is an enduring belief that a specific mode of conduct or end-state of existence is personally or socially preferable to an opposite or converse mode of conduct or end-state.

Ugwuegbu (1994) stated that values simplify people's life choices and guide them in setting life goal because values possess strong motivational components. Most values are conditioned by experience and socialization. Most people internalize their most important values so that when these values are internalized, they no longer need reinforcement by the individual. It is at this stage of internalization that a value consciously or unconsciously becomes a standard or criterion for action. This makes it useful for developing and maintaining attitudes towards relevant objects and situations for justifying one's own and others action and attitudes for morally judging oneself and others Ugbuegbu (2004). It is at this stage he stated further, a value becomes a standard people in authority such as parents and teachers employ to influence the values, attitudes and actions of their children and pupils.

Some parents value accumulation of wealth irrespective of how it is gotten and impart such notion or even set such as a standard for their children. This is why it is no longer surprising that most people in the society have been made to place more value on wealth, which everyone is interested in acquiring. So that what now matters, is the wealth an individual has and not how he acquires it. This distortion in the value system has led to a rise in all forms of criminal and deviant behaviour, which is expressed in trafficking (Onyenoru, 2001).

Values are hierarchical and this differs from one person to another in the sense that the most important value of an individual may be the least or median in the hierarchy of another's. More importantly, values are not static but dynamic. Values can be either positive or negative. Gold (2002) summarised the concept of values as ideas, which are shared by people about 
what is good or bad, right or wrong, desirable and undesirable. It therefore follows that the concept of value is relative and contextual as what is valued in a particular society may not be in another.

In traditional societies, most families want to have many children. They believe that children are economically helpful or valued for religious and other reasons. For instance among the Ibos, the number of children a woman bears and their sex enhance her social status (Owumi et al, 2003). However, in urban and industrialised societies which are presently considered as "modern", less importance is attached to large families. Cases still occur whereby some families in Nigeria especially those in the rural areas who are sometimes not literate, produce large families saying that children are gifts from God that cannot be rejected. They end up sending-their kids to work for families so that such children can ensure their survival and those of their parents and siblings. Some of these children become bait for trafficking.

\section{Psychological Implications of Human Trafficking}

It has been observed that some parents who are involved in trafficking their relatives find the act as a rewarding act which puts food on their table so that there is hardly any family you find that does not have a relative abroad (Nwoha, 2006). This is because for those in this subculture, the fact that one has a relative abroad irrespective of what he or she is doing abroad is a thing of pride as they are expected to send hard currency. In this regard, the phenomenon of trafficking is not only rampant due to poverty, but a process of being amongst the 'Joneses' whereby relatives abroad are expected to send "western union" as it is often called.

Owumi et al (1981) observed in their study that in traditional African societies, the practice of allowing one's children to be fostered for relatively long periods is common. This, they said is viewed as a form of social exchange, and is to some a way to encourage unity and to some others a way of relieving the family of the economic burden of bringing up the children. Some of these children end up becoming baits for trafficking. Furthermore, the preference for a male child is rampant in the communities that practice the system of primogeniture in which only the male child has rights to his father's wealth as is often practised in Edi state. This places the girl-child of such a family at a disadvantaged position making such girls vulnerable to human traffickers (Onyeonoru 2001).

\section{Urbanization: Familial changes and Human Trafficking}

The family is clearly the oldest and longest surviving of all human institutions. In pre-urban societies, the human community was virtually synonymous with the large extended. Gold (2002) stated that the family like religion was a "sacred" institution which was beyond questioning and open criticism. 
However, like all other institutions, changes that have affected the forms and the functions of the family coincided with and were the products of the urban industrial revolution. Overtime, there was a displacement of the extended family as the dominant form of family organization by the smaller and more mobile nuclear family. He further stated that in recent decades, the nuclear family has been threatened by continuing forces of economic, technological, social and cultural changes which are the effects of urbanization. Moreover, the increasing desire and urge to migrate from rural to urban areas where the level of individualism is very high has contributed to the persistence of human trafficking and other crimes (Tylor 2002).

\section{Distortion of Social Values and Human Trafficking in Edo State}

This is obvious or manifested in the increased lust for money and wealth especially illegally acquired wealth), greed and dissatisfaction in Nigeria. These were attributed to part of the legacy of military rule and have a relationship with the sex trade according to a respondent cited by Onyeonoru (2001). Adekanye (1993) buttressed this point by explaining how the military ruling class manipulated the public sector wage structure in Nigeria to unjustifiably place itself at the top. He stated that the combination of economic crisis, military dictatorship, political corruption and freedom to display illegally acquired wealth distorted the value system of Nigeria. Harsch (2001) confirmed this by stating some of these factors as being responsible for the persistence of human trafficking, despite of the attempts to curb it. Onyeonoru (2001) also related the distortion of social values in Nigeria as finding its expression in the system of justice. When offences are now sanctioned, they exacerbate deviance.

Olopoenia (1998) expressed in the words of one respondent he studied that people get contaminated and committed crimes because they observe that some others who committed similar crimes were not punished. As a result, individuals even tend to commit more grievous offences because they engage in "unhealthy competition." This, the respondent stated is a reflection of the twist in our social values which he said, has a bandwagon effect. Olopoenia (1998) explained that widespread systemic corruption occurs in which any anti-social behaviour in an office tends to become the norm when individuals loose confidence in the state's law enforcement apparatus. The problem of widespread systemic corruption as expressed by Olopoenia (1998) results in a situation where people become affected by the short-cut syndrome which has been identified as "driving the girls to travel" as explained by a respondent in the study conducted by Onyeonoru (2001). He stated that economic pursuits become stripped of their moral content as the commercial sex trade would suggest when the regulation of social order is weakened. 


\section{Theoretical Framework}

\section{- Anomie Theory}

The anomie theory of Merton (1949) which was revised in (1968) will form the corner stone around which the analysis would hinge. Merton explained that society in its bid to maintain order sets out values and standards in form of goals and means, which refers to the basic necessities for man's survival in his environment. It goes further to stipulate the values guiding how these necessities or "goals" should be achieved (means). Members of society strive to achieve these goals with the consciousness of the available means. Scarcity of resources as well as the unequal distribution of these means for achieving the set goals, cause individuals to conform or deviate in four ways such as ritualism, retreatism, rebellion and innovations.

Ritualism is displayed when individuals abandon the commonly held success goals. The pressure to do this according to Merton is greatest for members of the lower middle class. This is because their occupations provide less opportunity for success than those of other members of the middle class. In this sense, therefore the ritualist rejects the goals prescribed by the society and accepts the means of achievement.

The Retreatists are more or less the psychotics or outcast in the society some of whom include chronic drunkards and drug-addicts. They have strongly internalized both the cultural goals and the means of reaching them. They are unable to cope and 'drop out' of the society, defeated and resigned to their failure. They are deviant in two ways: they have rejected both the cultural goals and the means.

Rebellion is reflected when individuals in the society reject both the success goals and means and replace them with different goals and means. Those who adopt this alternative wish to create a new society. Merton argues that 'it is typically members of a rising class rather than the most depressed strata who organize the resentful and rebellious into a revolutionary group.'

Of great importance to explaining the phenomenon under study are the innovators. This category refers to those who know and accept the means of achieving the good things of life but choose to invent new means largely because the "approved" means are scarce and unavailable or difficult. The invented means are usually a deviation from those stipulated by the society. An average parent knows that it is his/her responsibility to adequately cater for their children. However due to economic hardship they can hardly play this role. Most parents are predisposed to trafficking their children because of poverty and unemployment. This is in accordance with the views of Harsch (2001) that poverty is a a major and ubiquitous causal factor of child trafficking, which greatly limits vocational and economic opportunities especially in rural areas. Poverty he stated pushes families to use all the available avenues to increase their meagre incomes. In the midst of this, changes in the structure of the family have affected care and support for family 
members in the sense that there is now shift from it being the collective responsibility of the extended family to the nuclear family alone.

Table 1: Demographic profile of trafficked girls at the two rehabilitation centres

\begin{tabular}{|c|c|c|c|c|}
\hline Variables & Category & Frequency & Percentage & Total \\
\hline \multirow{3}{*}{ Age } & $14-19$ & 14 & 64 & \multirow{2}{*}{22} \\
\cline { 2 - 4 } & $20-25$ & 6 & 27 & \\
\cline { 2 - 4 } & $26-30$ & 2 & 9 & \multirow{2}{*}{22} \\
\hline \multirow{3}{*}{$\begin{array}{c}\text { Educational } \\
\text { Status }\end{array}$} & Primary & 8 & 36 & \\
\cline { 2 - 4 } Religion & Secondary & 4 & 45 & \multirow{2}{*}{22} \\
\cline { 2 - 4 } & Drop-outs & 10 & 64 & \\
\cline { 2 - 4 } & Christianity & 14 & 9 & 22 \\
\cline { 2 - 4 } & Muslim & 2 & 100 & 22 \\
\hline Marital status & Traditional & 6 & 100 & 22 \\
\hline occupation & unemployed & 22 & \multicolumn{2}{|c}{} \\
\hline
\end{tabular}

The analysis reveals that $64 \%$ of trafficked girls fall within the ages of $14-$ 19. This is the age bracket in which young people venture out and express the need for their independence Harsch (2001). It is also the age-range within which a lot of youthful exuberance is displayed.

The increase drive for experimentation and exploration makes it easy for the girls to be easily influenced into trafficking activities by either their peers, traffickers and other individuals they interact with. Previous studies have also revealed that girls who are vulnerable to trafficking or trafficked, fall within this category (Mirkinson 1994, Onyeonoru 2001, Tylor 2002). Most of the girls that are trafficked are school dropouts. This is confirmed by the magazine published by the Idia Renaissance (2003). Ten (46\%) of the twenty-two (22) girls are school-drop while $8(36 \%)$ of the girls had primary education. Only 4 $(18 \%)$ of the girls interviewed had a secondary education. None of the girls interviewed had tertiary education. Furthermore, a high percentage of the trafficked girls practise Christianity. Over $64 \%$ of the trafficked girls are Christians. This may, however, be because a greater percentage of the population of the Benin people practise Christianity. Only 27\% of the girls said they are traditional worshippers while $9 \%$ claimed to be Muslims. Concerning marital status, all the 22 girls that were interviewed are single. None of these girls were employed, rather they all claimed to be are unemployed. These findings support the reports from other studies, which revealed that unemployment contributes a great deal to the vulnerability to trafficking activities. 
Table 2: Demographic profile of the parents of trafficked victims at rehabilitation centres

\begin{tabular}{|c|c|c|c|c|}
\hline Variables & Category & Frequency & Percentage & Total \\
\hline Type of family & Monogamy & 2 & 11 & \\
\hline & $\begin{array}{r}\text { Polygyny } \\
\text { No. of wives (2-4) } \\
(4-6) \\
\text { (above 6) }\end{array}$ & $\begin{array}{c}16 \\
10 \\
4 \\
2\end{array}$ & $\begin{array}{l}89 \\
56 \\
22 \\
11\end{array}$ & 18 \\
\hline $\begin{array}{c}\text { Parents } \\
\text { Employment }\end{array}$ & $\begin{array}{c}\text { Civil servant } \\
\text { Self employed } \\
\text { Unemployed } \\
\text { Private employee }\end{array}$ & $\begin{array}{l}4 \\
6 \\
7 \\
1\end{array}$ & $\begin{array}{l}22 \\
33 \\
39 \\
06\end{array}$ & 18 \\
\hline $\begin{array}{l}\text { Parents living } \\
\text { together }\end{array}$ & $\begin{array}{l}\text { Yes } \\
\text { No }\end{array}$ & $\begin{array}{c}2 \\
16\end{array}$ & $\begin{array}{l}11 \\
89\end{array}$ & 18 \\
\hline No. of siblings & $\begin{array}{c}4-6 \\
6-8 \\
8-10 \\
10 \text { \& above }\end{array}$ & $\begin{array}{l}2 \\
3 \\
6 \\
7\end{array}$ & $\begin{array}{l}11 \\
17 \\
33 \\
39\end{array}$ & 18 \\
\hline
\end{tabular}

An overwhelming population (89\%) of the girls that were interviewed at the rehabilitation centres are from polygynous families. Most of them (89\%) stated that their parents are no longer living together. It, therefore, follows that family disorganization contributes a large extent to the factors that push young girls into trafficking. Most of the children who participated in focus group discussions were not living with their parents. This was as a result of the fact that their parents had separated. Others complained that they had a very large family size, hence they had to live with other families as their maids in order to have an education or survive. Furthermore, $38 \%$ of the parents are unemployed, while $33 \%$ of them are self-employed and are mostly traders. The results from the FGDs are also revealed that most parents of girls vulnerable to trafficking are traders and farmers. The above findings further support earlier position that lack of skills and unemployment predispose individuals to trafficking (Onyeonoru, 2001; Idia Renaissance, 2003; Harsch, 2001).

The data also suggest that trafficking may be a function of family size. Hence, $33 \%$ of the trafficked girls come from homes with 8-10 children, and $9 \%$ from homes with more than ten children. The issue of large family size coupled with the problem of family disorganization and polygamy account for why children of such families are exposed to trafficking and child labour.

In line with findings from previous studies, the major factors that influence the persistence of human/child trafficking as revealed by most of the respondents especially the chiefs/opinion leaders and officials of the rehabilitation centres include the persistence of poverty, unemployment, 
distortion of cultural values, illiteracy, ignorance, family disorganization and greed. However much emphasis was laid on poverty and unemployment, which result from illiteracy and lack of skills. The girls interviewed at the rehabilitation centres emphasized persistent unemployment, poverty and family disorganization. A striking response from a girl from the rehabilitation centre summarises these factors thus:

Poverty pushed me into trafficking business, also I had no job to survive because I did not finish school; even my family too is very poor. My father left us for my mum when I was very small. When I became a bit matured, I was asked to travel with other girls abroad to work.

The above response also explains the fact that apart from poverty and unemployment, changes in family structure which is reflected in the separation of parents, contributes a great deal to the incidence of human trafficking. An interviewed parent confirmed poverty and large family size as an influencing factor of trafficking when she furiously said:

It's nobody's business if my daughter goes abroad to prostitute.

This is what we can do to survive or do you want us to die of hunger and poverty? Do you know how many people will die of hunger in my family if we don't do this?

The woman in question is seen as the breadwinner of her large family consisting of her extended family members because she is very wealthy as a result of the foreign currency sent to her by her daughter abroad. This supports the view that family values have changed and become distorted to the extent that wealth is celebrated regardless of its source. In line with the views of Giddens (1993), that extended family members migrate from rural areas to the cities to take advantage of the employment opportunities and resources believed to be available in urban areas. Presently, migration is not even undertaken with the belief that there are employment opportunities; rather it is done in order to survive. A number of responses revealed that trafficking might never be stopped as far as poverty and unemployment persist in Edo state. People will always seek for means, whether legal or illegal, to survive in the society. A respondent said;

Why will trafficking not continue when people still suffer because of poverty and lack of jobs? Even the jobs that are available cannot cater for an individual let alone a family. Only God can stop the problem of trafficking in Edo state.

Most of the respondents also stated that corruption is high in Nigeria, and that traffickers bribe their ways through. Hence, adequate punishment cannot be meted out to stop them as they can hardly be convicted. A parent in line with the above stated: 
Corruption is so high in Nigeria so that traffickers who exploit young girls and endanger their lives cannot even be convicted and punished. They bribe their ways through with the police, immigration officers, custom officers and even judges who more or less cannot resist the temptations of collecting such bribes because they are also not comfortable enough.

The above response reveals that economic hardship has eaten deep into the fabric of the society. As a result, even those who are expected to maintain law and order in the society can hardy do so because they are incapable of resisting temptations that involves financial and material rewards.

As revealed by the interviews carried out, most of the parents whose daughters are trafficked perceive it as a means of survival by which quick money is made to help the family out of their situation of difficulty or improve their lives. They see the idea of trafficking their daughters as a last resort in the struggle to survive. This corresponds with the Mertonian theory of the innovators who use illegal means to meet legal ends. A woman was reported to have almost committed suicide when her daughter was repatriated. Information had it that she had a party when the daughter travelled to Europe because she believed it was the dawn of a new day. A respondent (parent) said;

My daughter's travel abroad was the end of our suffering and poverty, so me I don't see any problem about allowing her to go no matter what she does abroad, she saved us. The idea that she travelled was perfect.

The above response reveals the level of distortion that our cultural values have been subjected to. Parents initially upheld decency and moral uprightness in the cause of nurturing their daughters. However, the quest for survival, greed and love of wealth and materialism have caused these values to be jettisoned.

Furthermore, perception is usually based on the success or failure of trafficking. A respondent confirmed this by saying;

If there is luck and money comes, the act is okay but if there is ill-luck and the child is repatriated, then it is considered a problem. However, we have to do something to survive.

Trafficking of a daughter or daughters in the above light is seen as a form of sacrificial attempt made by the family of an individual to help the family move forward, a form of gambling carried out to survive despite the risks. It is perceived to be a source of hope, which when successful, is "luck", and when not successful, is a result of lack of luck. 
Generally, trafficking of girls and young women in Edo state is seen as a problem, although respondents in the FGDs stated that the involved persons do not see it this way, rather they see it as a normal and necessary thing to do to survive. Only when they have lost a dear one, or fail in the act and lose their investments, do they start seeing it otherwise.

\section{Conclusion}

Human trafficking especially the trafficking of children, is an endemic phenomenon that needs to be seriously checked especially in Edo state. The most rampant form of trafficking is the one which involves taking the persons abroad to engage in all forms of labour. But there is another form that involves taking a child to live with another family to be a housemaid; the education and care of such a child is assured which might not be the case in the family. However, children taken to such homes are most times treated like slaves and are deprived of true parental love and care they deserve.

This phenomenon is very rampant because some parents especially those from the lower class give birth to more children than they can cater for. In the bid to ensure their future upkeep, they push the children to work for family friends or family members so that the economic burden of taking care of them can be reduced.

Furthermore, the problem of separation and family disorganizaion has made many children from these homes vulnerable to traffickers; separation affects the children's happiness and makes them leave their homes in search of comfort, happiness and a sense of belonging. These problems coupled with the problems of poverty, unemployment, greed and large family size has ensured the continuity of human trafficking especially in Edo state. Following the fact that human trafficking is not advantageous, especially to the children and for the country's image, there is need for collective efforts to curb the phenomenon.

In line with this, the study recommends that government should intensify efforts at alleviating poverty and creating employment opportunities and empowering the people in Edo state economically. This could be done by making credit and loans available to parents and young ladies who want to start businesses to earn a living. Also young school dropouts should be trained and guided to live a decent and meaningful life particularly in the cities.

Government and non-governmental bodies should ensure that proper enlightenment programs that emphasize the ills of trafficking are organized to discourage those who are vulnerable in rural and urban areas. Laws enacted against traffickers and trafficking acts should be strictly implemented.

The study also recommends that persons from Edo and other states where family disorganization is rampant should be enlightened on the negative effects of large family size, family disorganization, separation or divorce and the harmful effect of neglect and abandonment especially in polygynous marriages. The problems of single parents should be taken into consideration and adequate support provided for the single parent and the neglected child. Above all, the 
study recommends individual and collective fight against unemployment, corruption and trafficking of persons in Edo state.

\section{References}

Aderanti, A. (1997) Family, Population and Development in Africa, Zed books Limited, London.

Adekanye, B. (1993) Military Occupation and Social Stractification. A paper presented at an inaugural lecture, University of Ibadan.

Basil, H. (2000) Idia Renaissance: Dignifying womanhood. Making sex work safe network. Sex works projects in collaboration with AHRTAG, London U.K. 2001.

Caldwell, J.; Caldwell, P. and Orubuloye, O. (1994) The family and sexual networking in Sub-Saharan Africa; Historical/Regional Diffferenes and Present day implications in: Orubuloye, O.; Caldwell, J. and Santow, G. (eds) Sexual Networking and AIDS in Sub-Saharan African: Behaviour Research and the Social Context, H.T.C. The Australian National University.

Carter, B. and McGoldrick, M. (1999) The Expanded Family Life Cycle Individual, Family and Social Perspective. Library of Congress Cataloguing Publication Data.

Chinoy, E. (1967) Society: An Introduction to Sociology, Random House, New York.

Davis, E. (1954) The Demographic Foundation of National Power in Morroe Berge Theodore Abel and Charles H. Page (eds.). Freedom and Control in Modern Society. New York D. Van Nostrand PP. 206-42.

Giddens, A. (1991) Sociology, London: Polity Press.

Gideon, A. (1993) The Consequences of Modernity, Cambridge. England polity. Idia Renaissance, female trafficking (notes 2), Idia Renaissance Benin.

Gold, H. (2002) Urban Life and society. Pearson Education Inc. Upper Saddle River, New Jersey.

Harsch, E. (2001) Child Labour rooted in Africa's Poverty; Part of special feature: Protecting Africa's Chidren. A paper from Africa Recovery, Vol. 15 No. 3.

Haralambos, M.; Holborn, M. (2004) Sociology: Themes and Perspectives Fourth Edition. Happer Collins Publishers Limited Hammersmith London.

Idia Renaissance (2006) Idia Renaissance a global campaign against human trafficking and HIV/AIDS, an annual bulletin published by Idia Renaissance.

Merton, R. (1968) Social Theory and Social Structure (Enlarged edition). The Free Press New York. 
Msimange, S. (2003) Women Reinventing Globalisation. HIV/AIDS, Globalisation and the International Women's Movement Journal of Gender and Development 4(1).

Murdock, G. (1945) The Common Denominator of Cultures in Ralph Linton (eds). The Science of Man in the World Crisis. New York: Columbia University Press.

Ocholla-Ayayo, A.B.C. (1985) 'Ethic, customs and population control in Kenya', Working Paper No. 5, Nairobi: PSRI, University of Nairobi.

Stone, L. (1977) The Family, Sex and Marriage in England, 1500-1800. London.

Ocholla-Ayayo, A.B.C. (1991) 'The spirit of a nation: an analysis of policy, ethics and customary rules of conduct for regulating fertility levels in Kenya', Nairobi: Shivikon Publishers.

Onyeonoru, I. (2001) Push Factors in Girl Trafficking for Work and the Gender Implication. A Study of Benin, Edo State. African Journal of Peace and Conflict. Vol. 1, No. 1.

Otite, O. \& Ogionwo, O. (1979) Introduction to Sociological Studies Heinemann Edicational Books (Nig.) Ltd., Ibadan.

Rath, Harmins and Simon (1966) Values and Teaching: Working with Values in classroom Columbus, Ohio: Charles Merrill.

Rokeah, M. (1970) Beliefs, Attitudes and Values. A Theory of Organization and Change. San Francisco: Jossey-Bass Publishers.

Stone, L. (1977) The Family, Sex and Marriage in England, 1500-1800 (London: Weidenfield and Nicolson).

Tylor, E. (2002) Trafficking in Women and Girls, Expert Group meeting, Glen Cove, New York, U.S.A.

Ugwuegbue, D. (1994) A Review of Basic Psychological Ingredients for a Successful Value Orientation. An invited paper presented at the National Orientation Agency Workshop. Enugu Nike Lake Resort, August 23rd to 26th.

Ugwuegbu, D. (2004) The Shift Tides of Value Orientation: A case for National Development. A valedictory lecture presented at the Faculty of the Social Sciences, University of Ibadan.

UNICEF/NPC (2001) Children and Women's Rights in Nigeria: A wake up Call, situation Assessment and Analysis of Nigeria.

Wallerstein, J. and Kelly, J. (1980) Surviving the Break-Up: How Children and Parents Cope with Divorce. New York, Basic Books.

Zimmerman, C. (2006) Stolen smiles: A Summary Report on the Physical and Psychological Health Consequences of Women and Adolescents Trafficked in Europe. European Commission's Daphne Programme and IOM document. 